\title{
Front Matter: Volume 9539
}

, "Front Matter: Volume 9539," Proc. SPIE 9539, Opto-Acoustic Methods and Applications in Biophotonics II, 953901 (30 July 2015); doi:

10.1117/12.2208099

SPIE. Event: European Conferences on Biomedical Optics, 2015, Munich, Germany 


\title{
Opto-Acoustic Methods and Applications in Biophotonics II
}

\author{
Vasilis Nłziachristos \\ Roger Zemp \\ Editors \\ 22-23 June 2015 \\ Munich, Germany \\ Sponsored by \\ SPIE \\ The Optical Society (United States) \\ With support from \\ ThorLabs (United Kingdom) \\ Topcon (Japan) \\ Toptica Photonics AG (Germany) \\ Zeiss (United States) \\ Published by \\ SPIE
}


The papers included in this volume were part of the technical conference cited on the cover and title page. Papers were selected and subject to review by the editors and conference program committee. Some conference presentations may not be available for publication. The papers published in these proceedings reflect the work and thoughts of the authors and are published herein as submitted. The publisher is not responsible for the validity of the information or for any outcomes resulting from reliance thereon.

Please use the following format to cite material from this book:

Author(s), "Title of Paper," in Opto-Acoustic Methods and Applications in Biophotonics II, edited by Vasilis Ntziachristos, Roger Zemp, Proceedings of SPIE-OSA Biomedical Optics Vol. 9539 (SPIE, Bellingham, WA, 2015) Article CID Number.

ISSN: 1605-7422

ISBN: 9781628417043

Copublished by

SPIE

P.O. Box 10, Bellingham, Washington 98227-0010 USA

Telephone +1 3606763290 (Pacific Time) · Fax +1 3606471445

SPIE.org

and

\section{The Optical Society}

2010 Massachusetts Ave., N.W., Washington, D.C., 20036 USA

Telephone 1 202/223-8130 (Eastern Time) · Fax 1 202/223-1096

http://www.osa.org

Copyright (c) 2015, Society of Photo-Optical Instrumentation Engineers and The Optical Society.

Copying of material in this book for internal or personal use, or for the internal or personal use of specific clients, beyond the fair use provisions granted by the U.S. Copyright Law is authorized by SPIE subject to payment of copying fees. The Transactional Reporting Service base fee for this volume is $\$ 18.00$ per article (or portion thereof), which should be paid directly to the Copyright Clearance Center (CCC), 222 Rosewood Drive, Danvers, MA 01923. Payment may also be made electronically through CCC Online at copyright.com. Other copying for republication, resale, advertising or promotion, or any form of systematic or multiple reproduction of any material in this book is prohibited except with permission in writing from the publisher. The CCC fee code is $1605-7422 / 15 / \$ 18.00$.

Printed in the United States of America.

Publication of record for individual papers is online in the SPIE Digital Library.

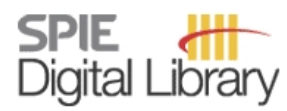

SPIEDigitallibrary.org

Paper Numbering: Proceedings of SPIE follow an e-First publication model, with papers published first online and then in print. Papers are published as they are submitted and meet publication criteria. A unique citation identifier (CID) number is assigned to each article at the time of the first publication. Utilization of CIDs allows articles to be fully citable as soon as they are published online, and connects the same identifier to all online, print, and electronic versions of the publication. SPIE uses a six-digit CID article

numbering system in which:

- The first four digits correspond to the SPIE volume number.

- The last two digits indicate publication order within the volume using a Base 36 numbering system employing both numerals and letters. These two-number sets start with 00, 01, 02, 03, 04, $05,06,07,08,09,0 A, 0 B \ldots$. OZ, followed by 10-1Z, 20-2Z, etc.

The CID Number appears on each page of the manuscript. The complete citation is used on the first page, and an abbreviated version on subsequent pages. 


\title{
Contents
}

\author{
$\checkmark \quad$ Authors \\ vii Conference Committee
}

\begin{abstract}
SESSION 1 TECHNOLOGY INNOVATION I
953905 Photoacoustic endoscopy probe using a coherent fibre optic bundle [9539-4]

953907 Polymer optical fibre sensors for endoscopic optoacoustic imaging [9539-6]

953908 Hybrid label-free multiphoton and optoacoustic microscopy (MPOM) [9539-7]
\end{abstract}

SESSION 2 CLINICAL APPLICATION

9539 OB Towards non-invasive imaging of surgical suture degradation with photoacoustic microscopy [9539-11]

9539 OC Coregistered photoacoustic and ultrasound tomography of healthy and inflamed human interphalangeal joints [9539-12]

9539 OD An interventional multispectral photoacoustic imaging plafform for the guidance of minimally invasive procedures [9539-13]

9539 OE Virtual intraoperative surgical photoacoustic microscopy [9539-14]

SESSION 3 TECHNOLOGY INNOVATION II

9539 0J Visualization of the microcirculatory network in skin by high frequency optoacoustic mesoscopy [9539-19]

9539 OK Fiber optic photoacoustic probe with ultrasonic tracking for guiding minimally invasive procedures [9539-20]

\section{SESSION 4 THEORY AND PROTOTYPING I}

9539 OM Laser-diode-based photoacoustic setup to analyze Grüneisen relaxation-effect induced signal enhancement [9539-22]

9539 ON Improvement of signal-to-noise ratio of optoacoustic signals from double-walled carbon nanotubes by using an array of dual-wavelength high-power diode lasers [9539-23]

9539 OP Analytical calibration of linear transducer arrays for photoacoustic tomography [9539-25]

$95390 Q \quad$ PhotoAcoustic-guided Focused UltraSound imaging (PAFUSion) for reducing reflection artifacts in photoacoustic imaging [9539-26] 


\section{SESSION 5 THEORY AND PROTOTYPING II}

9539 OS Fast photoacoustic imaging with a line scanning optical-acoustical resolution photoacoustic microscope (LS-OAR-PAM) [9539-28]

9539 OU High-resolution epi-illumination raster-scan optoacoustic mesoscopy for imaging of model organisms and microvessels [9539-30]

9539 OW Combined real-time ultrasound plane wave compounding and linear array optoacoustics [9539-32]

$95390 Z$ Light fluence correction for quantitative determination of tissue absorption coefficient using multi-spectral optoacoustic tomography [9539-35]

\section{POSTER SESSION}

953911 Characterisation of a PVCP-based tissue-mimicking phantom for quantitative photoacoustic imaging [9539-37]

953915 A system analysis and image reconstruction tool for optoacoustic imaging with finiteaperture detectors [9539-41]

953917 Speed-of-sound correction for photoacoustic and laser-ultrasound imaging with an integrating cylindrical detector [9539-43]

953918 Error estimates for universal back-projection based photoacoustic tomography [9539-44]

953919 Image reconstruction in cross-sectional optoacoustic tomography based on non-negative constrained model-based inversion [9539-45]

9539 1 A Light excitation methods for five dimensional optoacoustic imaging [9539-46] 


\section{Authors}

Numbers in the index correspond to the last two digits of the six-digit citation identifier (CID) article numbering system used in Proceedings of SPIE. The first four digits reflect the volume number. Base 36 numbering is employed for the last two digits and indicates the order of articles within the volume. Numbers start with 00, 01, 02, 03, 04, 05, 06, 07, 08, 09, 0A, 0B...0Z, followed by 10-1Z, 20-2Z, etc.

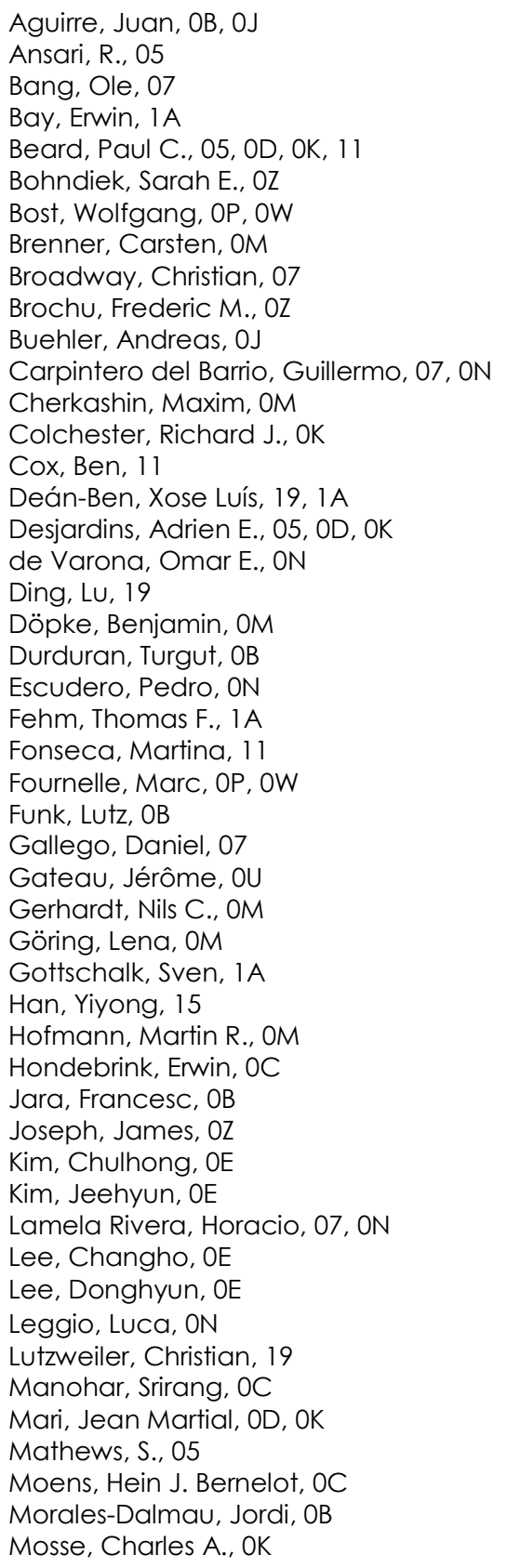

Munshi, Prabhat, 18

Naik, Naren, 18

Nikitichev, Daniil I., OD, OK

Ntziachristos, Vasilis, 08, 0J, 0U, 15, 19

Nuster, Robert, OS, 17

Oeri, Milan, OP

Omar, Murad, 08, 0J, OU

Osiński, Marek, ON

Ourselin, Sebastien, OD, OK

Paltauf, Guenther, 0S, 17

Pandey, Prabodh Kumar, 18

Pospori, Andreas, 07

Pradhan, Asima, 18

Razansky, Daniel, 19, 1 A

Rosenthal, Amir, 15

Schwarz, Mathias, OJ

Singh, Mithun K.A., $0 Q$

Soliman, Dominik, 08, OU

Steenbergen, Wiendelt, $0 C, 0 Q$

Tomaszewski, Michal, $\mathrm{OZ}$

Tretbar, Steffen, OW

Tserevelakis, George J., 08

Turon, Pau, OB

van Es, Peter, OC

van Hespen, Johan C. G., OC

Vlieg, Redmar C., OC

Webb, David J., 07

West, Simeon J., OD, OK

Woyessa, Getinet, 07

Wurzinger, Gerhild, 17

Xia, Wenfeng, OD, OK

Zeqiri, Bajram, 11

Zhang, E., 05

Zhou, Qifa, OE 
Proc. of SPIE Vol. $9539953901-6$

Downloaded From: https://www.spiedigitallibrary.org/conference-proceedings-of-spie on 26 Apr 2023 Terms of Use: https://www.spiedigitallibrary.org/terms-of-use 


\section{Conference Committee}

General Chairs

Andreas H. Hielscher, Columbia University (United States)

Jürgen Popp, Friedrich-Schiller Universität Jena (Germany)

Programme Chairs

Rainer Leitgeb, Medizinische Universität Wien (Austria)

Nirmala Ramanujam, Duke University (United States)

Conference Chairs

Vasilis Ntziachristos, Helmholtz Zentrum München GmbH (Germany)

Roger Zemp, University of Alberta (Canada)

Conference Program Committee

Emmanuel Bossy, Ecole Supérieure de Physique et de Chimie Industrielles (France)

Stanislav Y. Emelianov, The University of Texas at Austin (United States)

Jan Grimm, Memorial Sloan-Kettering Cancer Center (United States)

Fabian Kiessling, Universitätsklinikum Aachen (Germany)

Michael C. Kolios, Ryerson University (Canada)

Srirang Manohar, Universiteit Twente (Netherlands)

Matthew O'Donnell, University of Washington (United States)

Alexander A. Oraevsky, TomoWave Laboratories, Inc. (United States)

Guenther Paltauf, Karl-Franzens-Univesität Graz (Austria)

Amir Rosenthal, Helmholtz Zentrum München GmbH (Germany)

Lihong V. Wang, Washington University in St. Louis (United States)

Vladimir P. Zharov, University of Arkansas for Medical Sciences

(United States)

Session Chairs

1 Technology Innovation I

Roger Zemp, University of Alberta (Canada)

2 Clinical Application

Srirang Manohar, Universiteit Twente (Netherlands)

3 Technology Innovation II

Vasilis Nłziachristos, Helmholtz Zentrum München GmbH (Germany) 
4 Theory and Prototyping I

Daniel Razansky, Helmholtz Zentrum München GmbH (Germany)

5 Theory and Prototyping II

Benjamin T. Cox, University College London (United Kingdom) 